\title{
BADAK JAWA SEBAGAI SUMBER INSPIRASI DALAM PENCIPTAAN SENI KRIYA LOGAM
}

\author{
M. Imam Khamdani
}

\begin{abstract}
Creating an artwork with javan rhino as the source of inspiration was based on the author's interest towards rhinoceros especially javan rhino. Javan rhino has its own uniqueness compared to other species of rhinoceros and the phenomenon of its extinction that happened nowadays such as the skin's physical form that is folded as if it's forming an armor, its horn, and javan rhino is considered as an animal that is almost extinct so the author was interested in creating a metal craft artwork with Javan rhino as the theme in this final project as well as the requirement to graduate from bachelor degree of craft major.

The methods of approach used are the expressive, contemplation, aesthetic, and then the data collection was done by using literature study and observation methods. The artworks created through three stages : exploration, design, and embodiment. Metal art presented in this final project is a figurative artwork and the object was developed which is the result of Javan rhino embodiment.

The produced artwork is a three-dimensional metal craft artwork with the shape of Javan rhino as the inspiration of the craft art's creation and has a shape development in such a way. This artwork is expected to communicate with the society properly. This metal craft artwork was created neither for finding solutions nor solving the problems, but it is a touch of expression and a means of delivering a personal idea which is presented especially for art lovers and generally for the society.
\end{abstract}

Keywords: Javan rhino, Crafts art, Metal craft

\section{INTISARI}

Menciptakan karya dengan sumber inspirasi Badak Jawa didasari atas ketertarikan penulis terhadap binatang badak khususnya badak Jawa. Badak Jawa memiliki keunikan tersendiri dari badak lainnya dan fenomena kepunahan yang terjadi saat ini seperti bentuk fisik kulit badak yang belipat seperti membentuk baju baja, cula, dan tergolong hewan yang hampir punah sehingga penulis tertarik untuk menciptakan sebuah karya seni kriya logam bertemakan badak Jawa ke dalam tugas akhir ini sekaligus sebagai syarat menyelesaikan studi S1 jurusan kriya

Metode pendekatan yang digunakan adalah ekspresi, kontemplasi, estetis, kemudian metode pengumpulan data dilakukan dengan studi pustaka dan observasi. Proses penciptaan karya seni ini memalui tiga tahapan yaitu, eksplorasi, perancangan, dan perwujudan. Karya logam yang disajikan dalam Tugas Akhir ini merupakan karya figuratif dan dikembangkan objeknya yang merupakan hasil dari perwujudan badak Jawa.

Hasil karya ini adalah seni kriya logam tiga dimensi dengan bentuk badak Jawa sebagai inspirasi dari penciptaan seni kriya dan memiliki pengembangan bentuk yang sedemikian rupa. Diharapkan karya ini dapat berkomunikasi dengan masyarakat secara baik. Karya seni kriya

*) M. Imam Khamdani, Mahasiswa Program Studi S-1 Kriya Seni Jurusan Kriya, Fakultas Seni Rupa, Institut Seni Indonesia Yogyakarta. 
logam ini dibuat bukan dimaksudkan untuk mencari solusi ataupun menyelesaikan masalah, tetapi merupakan sebuah sentuhan ekspresi dan sarana penyampaian ide pribadi yang disampaikan kepada penikmat seni pada khususnya dan masyarakat pada umumnya.

Kata kunci: Badak Jawa, Seni kriya, Kriya logam

\section{PENDAHULUAN}

\section{Latar Belakang Penciptaan}

Seniman sebagai insan seni dalam menciptakan karya seni tidak terlepas dari unsur alam dan lingkungan yang ada di sekitarnya. Melalui lingkungan, seniman bisa melihat dan mengamati sebuah bentuk objek visual, baik objek hidup maupun objek yang mati. Daya tanggap dari seorang seniman atas fenomena-fenomena yang ada di alam menjadikan dasar bagi seorang seniman dalam berkarya. M. Supardi Sastrosupeno mengatakan bahwa, manusia memiliki hubungan yang erat dengan alam teristimewa dengan tanah, selain itu juga memiliki hubungan dengan udara, air, api, dan benda-benda serta makhluk lainnya. (M. Supardi Sastrosupeno 1984:10). Hubungan inilah yang mendasari penulis dalam membuat karya seni yang bertajuk Badak Jawa Sebagai Sumber Inspirasi Penciptaan Seni Kriya Logam.

Dalam menciptakan karya penulis Penulis mencoba mengembangkan bentuk yang diwujudkan atas dasar ekspresi pribadi ke dalam karya kriya seni, seperti yang diungkapkan oleh Susanne k. Langer bahwa seni itu tidak mengulang alam, tetapi sungguh menghasilkan sesuatu.(M. Sastrapraja,1998:74). Dengan pendapat dari Sussane K. Langer maka pengembangan bentuk atas ide dan konsep yang ada sangat berpengaruh bagi penulis untuk menciptakan karya seni kriya logam. Rasa peduli terhadap alam menjadikan manusia lebih sadar atau peka terhadap fenomena alam yang terjadi saat ini. Seperti halnya dalam berkarya yang memerlukan kepekaan terhadap sesuatu objek dan menjadikannya sebagai inspirasi dalam berkarya.

Badak Jawa (rhinoceros sondaicus) atau dikenal dengan nama badak bercula satu adalah anggota Famili Rhinocerotidae dan satu dari lima badak yang masih ada. Nama ini berasal dari Yunani, rhino yang berarti hidung, ceros berarti tanduk dan sondaicus berarti sunda. (Fitri R. Ghozali, 2011:8).

Badak merupakan mamalia besar yang paling langka di dunia dan mungkin hanya 50-60 ekor yang bertahan hidup di seluruh dunia, namun badak Jawa adalah jenis yang paling kecil di antara jenis badak lainya. Taman Nasional Ujung Kulon, Banten adalah salah satu lokasi habitat badak Jawa. (Ferli Zulhendri, 2008:37).

Ketertaikan penulis terhadap binatang badak Jawa memiliki beberapa alasan, pertama fenomena badak Jawa saat ini yaitu populasinya yang semakin menurun dan mengalami proses kepunahan yang disebabkan oleh perburuan liar. Kedua, bentuk dari badak Jawa yang memiliki keunikan pada bagian kulit berlipat-lipat, yang menyerupai baju perang. Sedangkan sifat dan kebiasaan hidup badak Jawa secara umum sama Badak Jawa Sebagai Sumber Inspirasi Seni kriya Logam seperti jenis badak lainnya, seperti berendam dalam lumpur, soliter (penyendiri), dan lain-lain. Cula badak 
dipercaya mimiliki khasiat sebagai obat kuat seperti mengandung keratin dan kalsium, inilah yang menjadi incaran para pemburu badak yang mengakibatkan menurunnya populasi badak. Penulis ingin mewujudkan sebuah figur badak Jawa dengan menampilkan bentuk yang di kembangkan oleh penulis menjadi sesuatu yang menarik untuk dilihat dan dapat dirasakan oleh penikmat seni.

Sebelum terciptanya sebuah bentuk, pengetahuan tentang bahan juga sangatlah penting di dalam seni kriya. Pengetahuan dan kesinambungan antara bahan dan objek yang nantinya akan dibuat sangat penting untuk diperhatikan. Bahan yang akan dipakai adalah logam berjenis alumunium. Sementara teknik yang akan digunakan adalah teknik cor. Karakteristik alumunium yang dipadukan dengan objek badak Jawa menampilkan nilai estetik tersendiri dan kepuasan batin bagi penulis Maka penulis pun ingin memvisualkan keinginan tersebut lewat karya seni, sekaligus untuk menuangkan pikiran dan perasaan tersebut kepada masyarakat umum melalui karya seni kriya.

\section{Hasil dan Pembahasan}

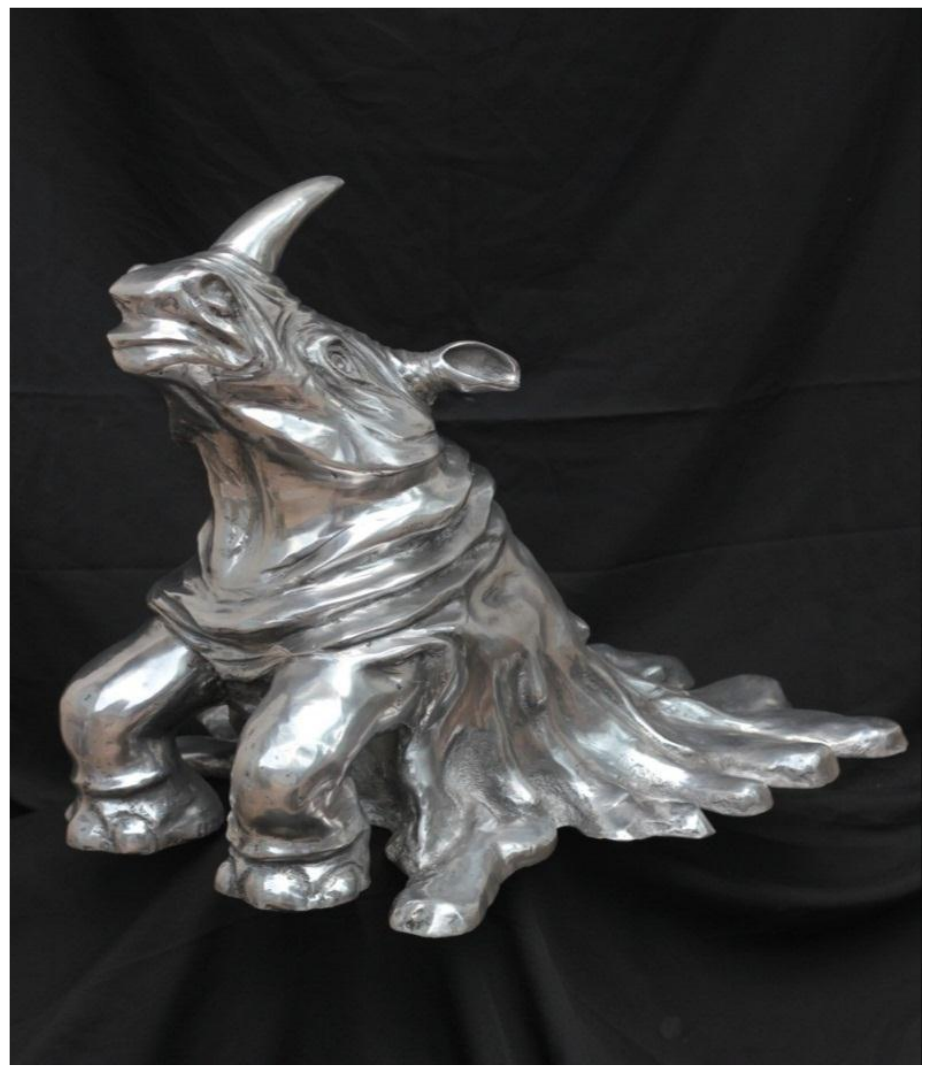

Gambar 1. Karya 1 Judul Karya "Kuingin Keluar",Ukuran: Variable Dimension,Teknik: Cor Alumunium, Bahan : Alumunium, Finishing: Poles, Candy Tone, Tahun Pembuatan: 2015, Fotografer: Ika Nurcahyani.

Kuingin keluar adalah sebuah luapan emosi yang tidak tahan terhadap ketidaknyamanan atas suatu perihal. Penggambaran badak dengan kedua kaki 
depan menapak dengan kuat seolah ingin keluar dari zona yang dialami. Badak merupakan binatang yang hampir punah sehingga mengakibatkan adanya perlindungan dan ketidakbebasan dalam hidupnya, menyuratkan untuk keluar dari zonanya yang sekarang dan ingin bebas seperti dahulu dengan tanpa ancaman dari manapun. Sama halnya luapan emosi dari penulis yang ingin keluar dari zona yang sekarang dialami.

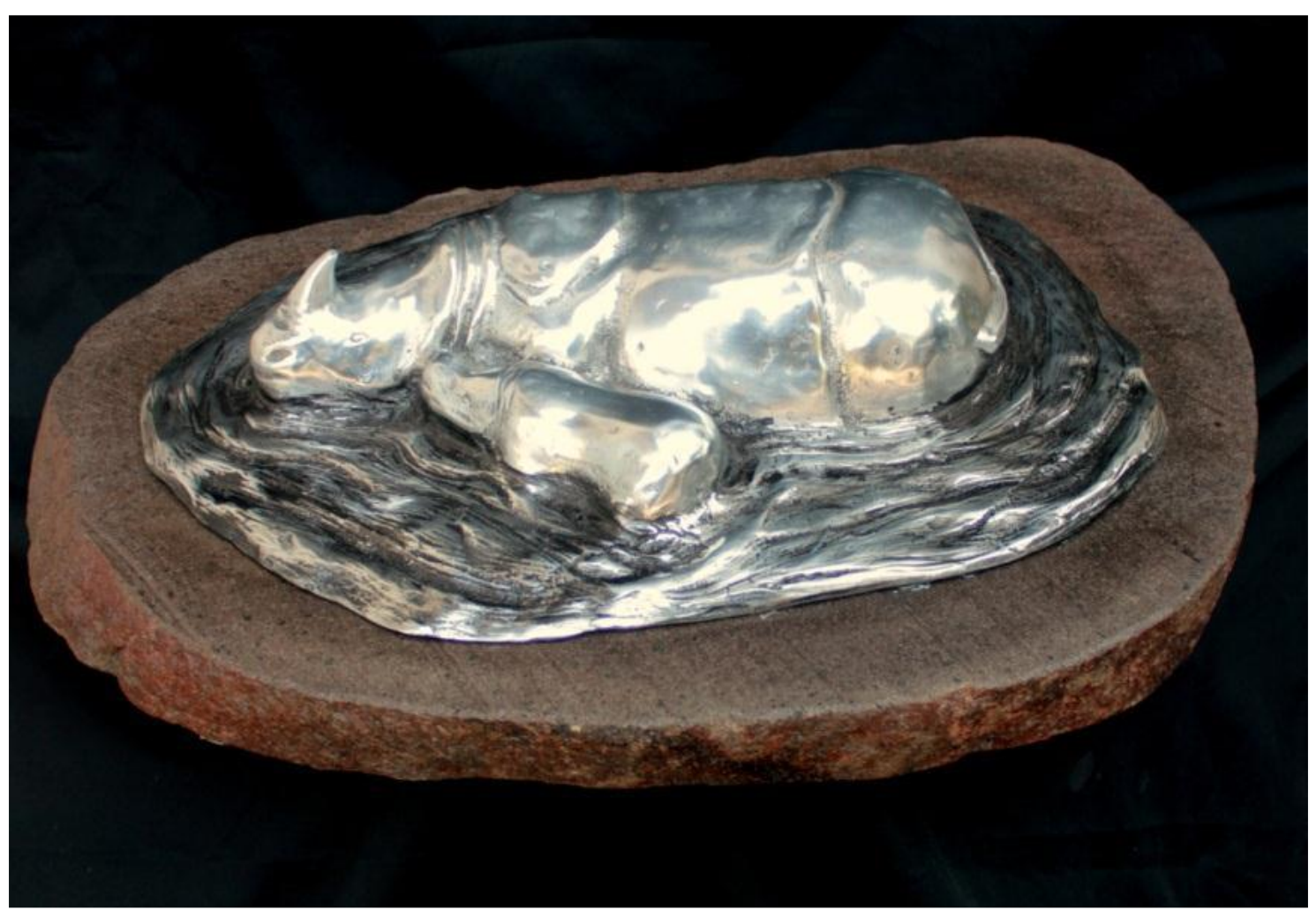

Gambar 2. Karya 2 Judul Karya "Kumkum”, Ukuran: Variable Dimension, Teknik: Cor Alumunium, Bahan : Alumunium, Finishing: Poles, Candy Tone, Tahun Pembuatan: 2015, Fotografer: Ika Nurcahyani.

Kumkum adalah proses merendam badan ke dalam air sehingga badan menjadi rileks. Dalam hidup perlu adanya sebuah tempat atau sesuatu yang membuat kita nyaman dan rileks. Kenyamanan membuat pikiran tenang dan emosi dapat terkontrol, sama halnya kebiasaan badak yang suka berendam di dalam kubangan lumpur menjadikannya nyaman, seperti tanpa adanya beban dan dapat menghilangkan kejenuhan yang ada. 


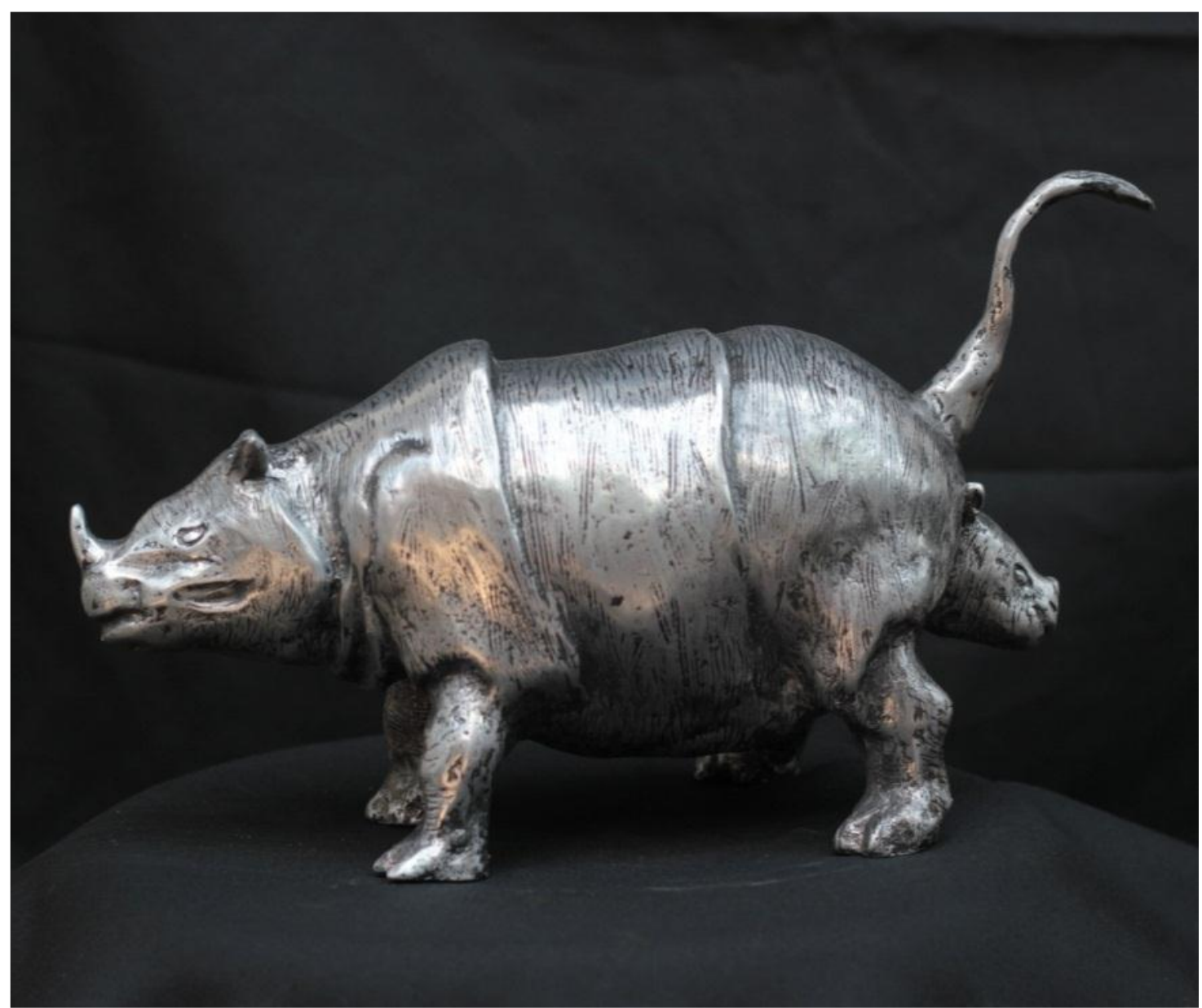

Gambar 3. Karya 3 Judul Karya “Muncul Penerus”,Ukuran: Variable Dimension, Teknik: Cor Alumunium, Bahan : Alumunium, Finishing: Poles, Candy Tone, Tahun Pembuatan: 2015, Fotografer: Ika Nurcahyani.

Muncul penerus merupakan sebuah penggambaran adanya penerus baru yang akan menggantikan generasi lama. Rergenerasi dibutuhkan untuk melangsungkan pemikiran-pemikiran yang tertunda karena hakekatnya semua makhluk hidup tidak ada yang abadi. Dengan adanya generasi yang baru maka sebuah perubahan pun akan muncul dengan banyak harapan. Seperti yang digambarkan dalam karya ini dengan iduk badak yang akan melahirkan sebuah generasi yang baru demi melangsungkan generasinya yang terancam punah, dengan harapan populasinya akan bertambah seperti dahulu kala.

\section{Kesimpulan}

Berekspresi melalui karya seni adalah sesuatu yang mengesankan bagi penulis, bukan hanya berkspresi secara bebas namun dalam mengekspresikan sebuah karya seni memerlukan sebuah ketelitian, ketekunan, dan pengetahuan. Proses kreatif sangat diperlukan guna menyusun sebuah karya dan memecahkan 
sebuah masalah atau kendala dalam menciptakan karya.

Dengan meminjam bentuk yang ada di alam penulis berupaya menyalurkan hasil renungannya ke dalam sebuah bentuk karya kriya logam. Hasil renungan yang terinspirasi dari kehidupan badak Jawa mengisayaratkan apa yang pernah dilalui oleh penulis. Sebuah hasil pemikiran dan pengalaman yang penulis alami dapat diungkapkan melalui karya kriya seni logam ini.

Penulis mendapatkan banyak pengalaman dan pengetahuan atas terciptanya karya seni ini yang secara tidak langsung menjadi proses pembelajaran dalam berkesenian. Dari proses yang perwujudan karya seni yang dijalani oleh penulis menimbulkan sebuah improvisasi atau perubahan yang terjadi terhadap karya seni ini yang semata-mata dilakukan untuk mencari sebuah nilai estetis dan pengembangan ide secara alami dari penulis terhadap karyanya.

Dalam penciptaan tugas akhir ini penulis berupaya dan berusaha semaksimal mungkin untuk menyajikan sebuah karya yang terbaik namun penulis juga tidak lepas dari adanya ketidaksempurnaan. Penulis menyadari masih ada kekurangan dalam diri penulis, baik berupa penyajian karya maupun penulisan laporan. Keterbatasan pengetahuan dan pengalaman mengakibatkan banyak hal yang seharusnya dilakukan dan dilalui secara bertahap namun tidak dilakukan dalam mewujudkan karya seni. Penulis berharap karya seni yang disajikan dapat dinikmati oleh penikmat seni dari semua kalangan. Saran dan kritik yang membangun dibutuhkan bagi penulis untuk perkembangan dan pembelajaran dalam proses belajar.

\section{DAFTAR PUSTAKA}

Beumer, B.J.M. (1994), Ilmu Bahan Logam, Jilid I, diterjemahkan oleh B.S. Anwar, Bhratara, Jakarta.

Buchori Zainudin, Imam. (1989), "Pengembangan Desain Produk Kerajinan, Makalah Lokakarya Pekan Kerajinan Indonesia, Jakarta.

Ghozali, Fitri R. (2011), Mengenal Hewan Langka, Trias Yoga Kreasindo, Jakarta.

Gustami, Sp. (2007), "Butir-butir Mutiara Estetika Timur", Ide Dasar Penciptaan Seni Kriya Indonesia, November, Yogyakarta. (1991), "Seni Kriya Indonesia, Dilema Pembinaan dan Pengembangannya", Pidato IImiah Dies Natalis Ketujuh Institut Seni Indonesia Yogyakarta, Yogyakarta.

Guntur. (2001), Teba Kriya, ARTHA, Surakarta.

Hartoko, Dick. (1984), Manusia dan Seni, Kanisius, Yogyakarta.

Koestoto Soebekti, Ir.lbnu Maryanto \& Widaeti. (2005), Mamalia Yang Dilindungi Di Indonesia, Jilid I, PT. Balai Pustaka, Jakarta.

Muchtar, But. (1 oktober 1991), "Daya Cipta Di Bidang Kriya", dalam SENI, Jurnal Pengetahuan dan Penciptaan Seni, BBP ISI, Yogyakarta.

Sastrapraja, M. (1998), Manusia Multi Dimensional, PT. Gramedia, Jakarta.

Sastrosupeno, M.Suprihadi. (1984), Manusia, Alam dan Lingkungan, Proyek Pengembangan dan 
Penerbitan Buku/Majalah

Pengetahuan Umum dan Profesi

Departemen Pendidikan dan

Kebudayaan, Jakarta.

Sp, Soedarso. (1990), Tinjauan Seni: Sebuah Pengantar untuk Apresiasi Seni, Saku Danar Sana, Yogyakarta.

Sudarmadji. (1879), Dasar-Dasar Kritik Seni Rupa, Dinas Musium dan Sejarah, Jakarta.

Read, Herbert. (1975), Pengertian Seni, terjemahan Soedarso Sp., ASRI, Yogyakarta.

Zulhendri, Ferli. (2008), Hewan-Hewan Langka di Indonesia, PT. Kiara Alifiani, Jakarta. 